\title{
PENGARUH PENDIDIKAN KESEHATAN TENTANG SADARI TERHADAP PENGETAHUAN DAN SIKAP REMA`JA PUTRI DALAM UPAYA DETEKSI DINI KANKER PAYUDARA DI SMA YASPEND PABA TAHUN 2017
}

\section{The Effect of Health Education About Conscious on Knowledge and Attitude of Youth Principlesi in Effort Early Detection of Breast Cancer in High School Yaspend Paba in 2017}

\author{
Dona Seniorita ${ }^{1}$ \\ ${ }^{1}$ Dosen Prodi D-III Kebidanan, Akademi Kebidanan Kharisma Husada \\ E-mail: nasutiondona38@ gmail.com
}

\begin{abstract}
Abstrak
Kanker payudara merupakan kelainan payudara yang paling ditakuti perempuan, karena penyakit ini tidak dapat disembuhkan jika ditemukan pada stadium lanjut. Usaha efektif untuk menemukan kanker payudara secara dini salah satunya adalah SADARI (Pemeriksaan Payudara Sendiri). Minimnya informasi dan upaya publikasi deteksi dini kanker payudara menyebabkan penemuan dan penanganan kanker belum bisa terkelola dengan baik. Salah satu upaya untuk memberikan informasi tentang SADARI kepada remaja putri adalah melalui pendidikan kesehatan.Jenis penelitian ini adalah penelitian eksperimen semu atau quasi experiment. Rancangan yang digunakan adalah pretestt-posttest with control group design. Populasi seluruh siswa putri SMA YASPEND PABA Binjai, sampel diambil 50 responden dengan menggunakan teknik simple random sampling, dibagi dua yaitu 25 sebagai kelompok kontrol dan 25 sebagai kelompok perlakuan. Uji statistik yang digunakan adalah uji mann whitney dengan $\alpha=5 \%$.Dari analisis data diperoleh bahwa ada pengaruh pendidikan kesehatan tentang SADARI terhadap pengetahuan $(\mathrm{p}=0,000)$ dan sikap $(\mathrm{p}=0,000)$ responden dalam upaya deteksi dini kanker payudara. Disarankan bagi pihak sekolah bekerjasama dengan Dinas Kesehatan melalui Dinas Pendidikan Kota Binjai untuk menyelenggarakan kegiatan penyuluhan mengenai SADARI. agar para remaja bisa menerapkan SADARI dengan rutin dalam kehidupan sehari-hari sebagai upaya deteksi dini kanker payudara.
\end{abstract}

Kata kunci: Pendidikan Kesehatan SADARI, pengetahuan, sikap, remaja putri, deteksi dini kanker payudara.

\begin{abstract}
Breast cancer is a breast disorder that is most feared by women, because this disease cannot be cured if found at an advanced stage. An effective effort to find breast cancer early is one of them is BSE (Self Breast Examination). The lack of information and efforts to publicize breast cancer early detection has led to the discovery and treatment of cancer that has not been managed properly. One effort to provide information about BSE to young women is through health education. This type of research is quasiexperimental research. The design used was pretestt-posttest with control group design. The population of all high school female students YASPEND PABA Binjai, samples were taken 50 respondents using simple random sampling technique, divided into two, namely 25 as the control group and 25 as the treatment group. The statistical test used is the Mann Whitney test with $\alpha=5 \%$.From the data analysis, it was found that there was an effect of health education about BSE on knowledge $(\mathrm{p}=0,000)$ and the attitude $(\mathrm{p}=0,000)$ of respondents in the effort of early detection of breast cancer.It is recommended for the school to work with the Health Office through the Binjai City Education Office to organize counseling activities on BSE. so that teenagers can apply BSE routinely in daily life as an effort to detect breast cancer early.
\end{abstract}

Keywords: BSE Health Education, knowledge, attitude, young women, early detection breast cancer.

\section{PENDAHULUAN}

Kanker payudara adalah masa ganas yang berasal dari pembelahan diluar kendali sel-sel yang ada di jaringan payudara. Kanker payudara dapat berasal dari jaringan payudara itu sendiri atau dari jaringan lain yang merupakan hasil metastase dari kanker lain (Hopkins,2008).

Menurut Organisasi Kesehatan Dunia (WHO) dari 2008 sampai 2012 kasus 
penderita kanker meningkat dari 1,4 juta menjadi 12,7 juta. Jumlah kematian yang disebabkan kanker melonjak dari 7.600.000 menjadi 8.200.000 dan lebih dari setengahnya berasal dari Negara berkembang. Data juga menunjukkan peningkatan pada kasus kanker payudara, sebanyak 1,7 juta jiwa wanita didiagnosis menjadi penderita penyakit kanker payudara pada tahun 2012 (David Forman dikutip oleh Kusmiyati 2013).

Kanker payudara merupakan penyebab utama kematian pada wanita di dunia.3 Globocan, IARC tahun 2012 menunjukkan CSDR kanker payudara di dunia adalah 12,9 per 100.000 perempuan. CSDR kanker payudara di seluruh wilayah dunia bervariasi, mulai dari 15,5 per 100.000 perempuan di Afrika Selatan; 14,1 per 100.000 perempuan di Asia Tenggara.

Di Indonesia kanker payudara merupakan kanker dengan insiden tertinggi nomor dua setelah kanker serviks dan terdapat kecendrungan meningkat dari tahun ke tahun. Jumlah kanker payudara di Indonesia didapatkan kurang dari 23.140 kasus baru setiap tahun. Menurut suatu penelitian di RS Cipto Mangunkusumo mendapatkan stadium IIIA dan IIIB sebanyak 43,4\%, stadium IV sebanyak $14,3 \%$, berbeda dengan negara maju dimana kanker payudara ditemukan lebih banyak dalam stadium dini (Suyatno., dan Pasaribu, E.T., 2010)

Bidang Pemberantasan Masalah Kesehatan (PMK) dinas kesehatan Sumut menjelaskan prevalensi penderita kanker di Sumut sebanyak 2,9, atau tiap 100 ribu orang diprediksi ada sekitar dua penderita kanker. Ini berdasarkan Riset Kesehatan Dasar (Riskesdas) 2010 di seluruh provinsi Indonesia (Jurnalis Perempuan, 2011).

Berdasarkan laporan dari Kemenkes RI Sumatera Utara kanker payudara masuk dalam kategori peringkat 10 besar tertinggi dari 33 provinsi di Indonesia. Kematian pada kasus kanker payudara pada negara berkembang dua kali lebih besar dibandingkan negara maju, hal ini terjadi selain karena kurangnya program skrining, juga diperparah dengan rendahnya kemampuan dan aksesibilitas untuk pengobatan.
Pendidikan kesehatan adalah proses untuk meningkatkan kemampuan masyarakat dalam memelihara dan meningkatkan kesehatan. Secara operasional, pendidikan kesehatan merupakan suatu kegiatan untuk memberikan dan atau meningkatkan pengetahuan, sikap, dan praktek masyarakat dalam memelihara dan meningkatkan kesehatan mereka sendiri (Notoatmodjo, 2003).

Pengetahuan merupakan hasil "tahu", dan terjadi setelah seseorang melakukan penginderaan terjadi melalui panca indera manusia, yaitu indera penglihatan, pendengaran, penciuman, rasa dan raba. Sebagian besar pengetahuan manusia diperoleh melalui mata dan telinga. Sebelum seseorang mengadopsi perilaku baru, di dalam diri orang tersebut terjadi proses yang berurutan :

a. Awarenes (kesadaran), dimana orang tersebut menyadari dalam arti mengetahui terlebih dahulu terhadap stimulasi (objek).

b. Interest (ketertarikan), ketertarikan terhadap stimulus atau objek tertentu, sikap subjek sudah mulai muncul.

c. Evaluation (evaluasi), baik dan tidaknya stimulus tersebut bagi dirinya, hal ini berarti sikap responden sudah lebih baik.

d. Trial, dimana sejak mulai mencoba melupakan sesuatu sesuai dengan apa yang dikehendaki oleh stimulis.

e. Adaption, dimana subjek telah berperilaku baru sesuai dengan pengetahuan, kesadaran dan sikapnya terhadap stimulus.

Menurut Notoatmodjo (2010), pengetahuan yang dicakup dalam kognitif mempunyai 6 (enam) tingkatan :

1. Tahu (Know), mengingat suatu materi yang telah terjadi sebelumnya atau mengingat kembali sesuatu yang spesifik dari seluruh bahan yang dipelajari atau rangsangan yang telah diterima. Oleh sebab itu, tahu merupakan tingkat pengetahuan yang paling rendah.

2. Memahami (Comprehensive), memahami diartikan sebagai suatu kemampuan untuk menjelaskan 
secara besar tentang objek yang diketahui dan dapat menjelaskan materi secara benar.

3. Aplikasi (Aplication), suatu kemampuan untuk menjelaskan secara besar tentang objek yang diketahui dan dapat menjelaskan materi tersebut secara benar.

4. Analisa (Analysis), kemampuan untuk menjabarkan materi atau subjek kedalam komponenkomponen, tapi masih dalam suatu organisasi dan masih ada kaitannya satu sama lain.

5. Sintesis (Syntesis), menunjukkan pada suatu kemampuan untuk melakukan, menghubungkan bagian-bagian dalam suatu bentuk keseluruhan yang baru.

6. Evaluasi (Evaluation), berkaitan dengan kemampuan untuk melakukan justifikasi atau penelitian terhadap suatu materi atau objek. Penilaian berdasarkan pada suatu kriteria yang telah ada.

Sikap adalah kecenderungan bertindak, berpersepsi, berpikir, dan merasa dalam menghadapi objek, ide, situasi atau nilai. Sikap bukan perilaku, tetapi merupakan kecenderungan untuk berperilaku dengan cara-cara tertentu terhadap objek sikap. Objek sikap boleh berupa benda, orang, tempat, gagasan atau situasi, atau kelompok. Jadi, pada kenyataannya tidak ada istilah sikap yang berdiri sendiri. Sikap haruslah diikuti oleh kata "terhadap", atau "pada" objek sikap. Bila ada orang yang berkata, "Sikap saya positif," kita harus mempertanyakan "Sikap terhadap apa atau siapa?” (Rakhmat, 2005: 39).

Kanker atau neoplasma merupakan suatu penyakit akibat adanya pertumbuhan yang abnormal dari sel-sel jaringan tubuh yang dapat mengakibatkan invasi ke jaringanjaringan normal. Definisi yang paling sederhana yang dapat diberikan adalah pertumbuhan sel-sel yang kehilangan pengendaliannya. Kanker dapat menyebar pada bagian tubuh tertentu seperti payudara (Smeltzer, 2002).

Kanker Payudara adalah tumor ganas yang menyerang jaringan kelenjar, saluran kelenjar dan jaringan penunjang payudara.
Kanker payudara terjadi karena adanya kerusakan gen yag mengatur pertumbuhan dan diferensiasi sel-sel pada payudara, sehingga sel-sel ini tumbuh dan berkembang biak tanpa dapat dikendalikan. Sel kanker ini dapat menyebar melalui aliran darah ke seluruh tubuh (Mardiana, 2004).

Menurut Nugroho (2011), faktor yang diperkirakan mempunyai pengaruh terhadap terjadinya kanker payudara diantaranya:

\section{a. Faktor reproduksi}

Karakteristik reproduktif yang berhubungan dengan resiko terjadinya kanker payudara adalah nuliparitas (wanita yang belum pernah melahirkan anak yang viable atau hidup), menarche (menstruasi pertama) pada umur muda, menopause pada umur lebih tua, dan kehamilan pertama pada umur tua (kehamilan pertama di atas 30 tahun).

Resiko utama kanker payudara adalah bertambahnya umur. Secara anatomi dan fungsional, payudara akan mengalami atrofi dengan bertambahya umur. Kurang dari $25 \%$ kanker payudara terjadi pada masa sebelum menopause, sehingga diperkirakan awal terjadinya tumor terjadi jauh sebelum terjadinya perubahan klinis.

b. Penggunaan hormon

Hormon estrogen berhubungan dengan terjadinya kanker payudara. Laporan dari Haevaed School of Public Health menyatakan bahwa terdapat peningkatan kanker payudara yang signifikan pada para pengguna terapi estrogen replacement.

Suatu meta analisis menyatakan bahwa walaupun tidak terdapat resiko kanker payudara pada pengguna kontrasepsi oral, wanita yang menggunakan obat

ini untuk waktu yang lama memiliki resiko yang tinggi untuk mengalami kanker payudara sebelum menopause. Sel-sel yang sensitif terhadap rangsangan hormonal mungkin mengalami perubahan degenerasi jinak atau menjadi ganas.

\section{c. Penyakit fibrokistik}

1. Pada wanita dengan adenosis fibroadenoma, dan fibrosis tidak ada peningkatan resiko terjadinya kanker payudara.

2. Pada hiperplasis dan papilloma, resiko sedikit meningkat 1,5 sampai 2 kali. 
3. Sedangkan pada hyperplasia atipik, resiko meningkat hingga 5 kali.

d. Obesitas

Terdapat hubungan yang positif antara berat badan dan bentuk tubuh dengan kanker payudara pada wanita pasca menopause. Variasi terhadap terjadinya kanker ini di negara-negara barat dan bukan barat serta perubahan sesudah migrasi menunjukkan bahwa terdapat pengaruh diet terhadap terjadinya keganasan ini.

e. Konsumsi lemak

Lemak diperkirakan sebagai suatu faktor resiko terjadinya kanker payudara.Willet dkk. melakukan studi prospektif selama 8 tahun tentang konsumsi lemak dan serat dalam hubungannya dengan kanker payudara pada wanita umur 34-59 tahun.

f. Radiasi

Terpapar dengan radiasi, ionisasi selama atau sesudah pubertas meningkatkan terjadinya resiko kanker payudara. Dari beberapa penilitian yang disimpulkan bahwa resiko kanker radiasi berhubungan secara linier dengan dosis dan umur saat terjadinya paparan.

g. Riwayat keluarga dan faktor genetik

Riwayat keluarga merupakan komponen yang penting dalam riwayat penderita yang akan dilaksanakan skrining untuk kanker payudara. Terdapat peningkatan resiko keganasan pada wanita yang keluarganya menderita kanker payudara. Pada studi genetik ditemukan pada kanker payudara berhubungan dengan gen tertentu. Apabila terdapat BRCA1, yaitu suatu gen kerentanan terhadap kanker payudara, probabilitas untuk terjadi kanker payudara sebesar $60 \%$ pada umur 50 tahun dan sebesar $85 \%$ pada umur 70 tahun. Faktor usia sangat berpengaruh sekitar $60 \%$ kanker payudara terjadi di usia 60 tahun. Resiko terbesar usia 75 tahun.

Menurut Taufan (2011) gejala klinis kanker payudara dapat berupa Benjolan pada payudara, umumnya berupa benjolan yang tidak nyeri pada payudara. Benjolan itu mula-mula kecil, semakin lama akan semakin besar, lalu melekat pada kulit atau menimbulkan perubahan pada kulit payudara atau pada puting susu. erosi atau eksema puting susu, kulit atau puting susu menjadi tertarik kedalam (retraksi), berwarna merah muda atau kecoklatcoklatan sampai menjadi oedema hingga kulit kelihatan seperti kulit jeruk (peau d'orange) mengkerut, atau timbul borok (ulkus) pada payudara. Borok itu semakin lama akan semakin besar dan mendalam sehingga dapat menghancurkan seluruh payudara, sering berbau busuk, dan mudah berdarah, Perdarahan pada puting susu dan Rasa sakit atau nyeri pada umumnya baru timbul apabila tumor sudah besar, sudah timbul borok, atau bila sudah muncul metastase ke tulang-tulang Kemudian timbul pembesaran kelenjar getah bening di ketiak, bengkak (edema) pada lengan, dan penyebaran kanker keseluruh tubuh.

Jenis-jenis kanker payudara yaitu (Tim CancerHelps, 2010) :

1) Duktal Karsinoma In Situ (DCIS) Jenis ini merupakan tipe kanker payudara non invasif paling umum.DCIS berarti sel-sel kanker berada di dalam duktus dan belum menyebar keluar dinding duktus ke jaringan payudara di sekitarnya. Sekitar satu hingga lima kasus baru kanker payudara adalah DCIS. Hampir semua wanita dengan kanker tahap ini dapat disembuhkan. Mammografi merupakan cara terbaik untuk mendeteksinya.

2) Lobular Karsinoma In Situ (LCIS) LCIS bukan kanker, tetapi terkadang digolongkan sebagai tipe kanker payudara non invasif. Bermula dari kelenjar yang memproduksi air susu, tetapi tidak berkembang melewati dinding lobules. Mammografi rutin sangat disarankan pada kanker tipe ini.

3) Invasif atau Infiltrating Duktal Karsinoma (IDC) IDC merupakan jenis kanker payudara yang paling umum dijumpai.Timbulnya sel kanker bermula dari duktus, menerobos dinding duktus, dan berkembang ke dalam jaringan lemak payudara. Kanker akan menyebar ke organ tubuh lainnya melalui system getah bening dan aliran darah. Sekitar 8-10 kasus kanker payudara merupakan jenis ini. 
4) Invasif atau Infiltrating Lobular Karsinoma (ILC) Kanker ini dimulai dari lobules. ILC sama seperti dengan IDC, dapat menyebar ke bagian lain di dalam tubuh.

5) Kanker Payudara Terinflamasi (IBC)

IBC merupakan jenis kanker payudara invasif yang jarang terjadi.Hanya $1-3 \%$ dari semua kasus kanker payudara adalah tipe IBC.Jenis ini biasanya tidak terjadi benjolan tunggal atau tumor pada payudara.Kanker jenis ini membeuat kulit payudara terlihat merah dan terasa hangat.Kulit payudara tampak tebal dan mengerut seperti kulit jeruk.

Penatalaksanaan kanker payudara dilakukan dengan serangkaian pengobatan meliputi pembedahan, kemoterapi, terapi hormon, terapi radiasi dan yang terbaru adalah terapi imunologi (antibodi). Pengobatan ini ditujukan untuk memusnahkan kanker atau membatasi perkembangan penyakit serta menghilangkan gejala-gejalanya. Keberagaman jenis terapi ini mengharuskan terapi dilakukan secara individual.

a. Pembedahan Tumor primer

biasanya dihilangkan dengan pembedahan. Prosedur pembedahan yang dilakukan pada pasien kanker payudara tergantung pada tahapan penyakit, jenis tumor, umur dan kondisi kesehatan pasien secara umum. Ahli bedah dapat mengangkat tumor (lumpectomy), mengangkat sebagian payudara yang mengandung sel kanker atau pengangkatan seluruh payudara (mastectomy). Untuk meningkatkan harapan hidup, pembedahan biasanya diikuti dengan terapi tambahan seperti radiasi, hormon atau kemoterapi.

b. Terapi radiasi

Terapi radiasi dilakukan dengan sinar-X dengan intensitas tinggi untuk membunuh sel kanker yang tidak terangkat saat pembedahan.

c. Terapi hormon

Terapi hormonal dapat menghambat pertumbuhan tumor yang peka hormon dan dapat dipakai sebagai terapi pendamping setelah pembedahan atau pada stadium akhir.

d. Kemoterapi Obat

Kemoterapi digunakan baik pada tahap awal ataupun tahap lanjut penyakit (tidak dapat lagi dilakukan pembedahan). Obat kemoterapi bisa digunakan secara tunggal atau dikombinasikan. Salah satu diantaranya adalah Capecitabine dari Roche, obat anti kanker oral yang diaktivasi oleh enzim yang ada pada sel kanker, sehingga hanya menyerang sel kanker saja.

\section{e. Terapi Imunologik}

Sekitar 15-25\% tumor payudara menunjukkan adanya protein pemicu pertumbuhan atau HER2 secara berlebihan dan untuk pasien seperti ini, trastuzumab, antibodi yang secara khusus dirancang untuk menyerang HER2 dan menghambat pertumbuhan tumor bisa menjadi pilihan terapi. Pasien sebaiknya juga menjalani tes HER2 unutk menentukan kelayakan terapi dengan trastuzumab.

\section{f. Mengobati Pasien}

Pada Tahap Akhir Penyakit Banyak obat anti kanker yang telah diteliti untuk membantu $50 \%$ pasien yang mengalami kanker tahap akhir dengan tujuan memperbaiki harapan hidup. Meskipun demikian, hanya sedikit yang terbukti mampu memperpanjang harapan hidup pada pasien, diantaranya adalah kombinasi trastuzumab dengan capecitabine. Focus terapi pada kanker tahap akhir bersifat paliatif (mengurangi rasa sakit). Dokter berupaya untuk memperpanjang serta memperbaiki kualitas hidup pasien melalui terapi hormon, terapi radiasi dan kemoterapi. Pada pasien kanker payudara dengan HER2positif, ttastuzumab memberikan harapan untuk pengobatan kanker payudara yang dipicu oleh HER2(Pierce, A., Neil, R., 2007)

Upaya deteksi dini kanker payudara adalah upaya untuk mendeteksi dan mengidentifikasi secara dini adanya kanker payudara sehingga diharapkan dapat diterapi dengan tehnik yang mempunyai efek samping yang lebih kecil dan mempunyai peluang yang lebih besar untuk sembuh (Depkes, 2010)

Oleh karena itu Komunikasi Informasi dan Edukasi (KIE) untuk meningkatkan kesadaran tentang tanda-tanda awal 
kemungkinan adanya kanker diantara petugas kesehatan, kader masyarakat, maupun masyarakat secara umum merupakan kunci utama keberhasilannya. Salah satu bentuk peningkatan kesadaran masyarakat tentang gejala dan tanda-tanda kanker payudara adalah dengan pemeriksaan payudara sendiri yang dikenal dengan istilah SADARI dengan cara memasyarakatkan program SADARI bagi semua perempuan mulai dari sejak usia subur, sebab $85 \%$ kelainan di payudara justru pertamakali dikenali penderita itu sendiri (Supit, 2005).

SADARI (periksaan payudara sendiri) adalah pengembangan kepedulian seseorang wanita terhadap kondisi payudara sendiri. Tindakan ini dilengkapi dengan langkahlangkah khusus untuk mendeteksi secara awal penyakit kanker payudara. Kegiatan ini sangat sederhana dan dapat dilakukan oleh semua wanita tanpa perlu merasa malu kepada pemeriksa, tidak membutuhkan biaya, SADARI hanya membutuhkan waktu selama lima menit. Cukup dilakukan saat mandi atau pada saat berbaring. SADARI sebaiknya mulai dilakukan saat seorang wanita sudah mengalami menstruasi (Kristiyansari, 2009)

SADARI adalah pemeriksaan payudara sendiri yang bertujuan untuk mengetahui ada tidaknya kanker dalam payudara wanita. Pemeriksaan ini dilakukan dengan meggunakan cermin dan dilakukan oleh wanita yang berumur 20 tahun ke atas (Olfah, 2013).

Tujuan dilakukan SADARI untuk mendeteksi adanya kelainan-kelainan pada payudara baik struktur, bentuk ataupun tekstur, mengetahui adanya kelainan pada payudara sejak dini, sehingga diharapkan kelainan-kelainan tersebut tidak ditemukan pada stadium lanjut yang pada akhirnya akan membutuhkan pengobatan rumit dengan biaya mahal. Selain itu adanya perubahan yang diakibatkan gangguan pada payudara dapat mempengaruhi gambaran diri penderita (Suryaningsih, 2009).

Pada wanita produktif, SADARI harus dilakukan sebulan sekali, 1 minggu setelah haid terakhir (10 hari setelah hari pertama haid) karena saat ini payudara kemungkinan tidak mengeras dan tidak nyeri. Jangan melakukan pemeriksaan payudara pada masa pertengahan siklus haid sampai menjelang haid, payudara biasanya membengkak akibat pengaruh kelenjar susu oleh hormon estrogen dan progesteron, sehingga pemeriksaan akan lebih sulit dilakukan secara akurat. Jika ibu tidak mendapat menstruasi lagi/sudah menopause, ibu harus memilih hari/tanggal yang sama setiap bulan (misalnya setiap tanggal 1 setiap bulan) untuk memeriksakan payudaranya secara teratur (Diananda, 2007).

Remaja yang dalam bahasa aslinya disebut adolescene, berasal dari bahasa latin adolescene yang artinya tumbuh atau tumbuh untuk mencapai kematangan. Bangsa primitive dan orang-orang purbakala memandang masa puber dan masa remaja tidak berbeda dengan periode lain dengan rentang kehidupan. Anak dianggap dewasa apabila sudah mampu mengadakan reproduksi (Hurlock, 2012).

Menurut WHO batasan usia remaja 12-24 tahun, namun jika pada usia remaja seseorang sudah menikah, maka ia tergolong dalam dewasa atau bukan lagi remaja. Sebaliknya, jika usia sudah bukan lagi remaja tetapi masih bergantung pada orang tua (tidak mandiri), maka dimasukkan dalam kelompok remaja (Widyastuti, 2009).

Irianto (2013), mengemukakan bahwa sebagian besar remaja ditandai oleh ciri-ciri pertumbuhan fisik, perkembangan seksual, cara berpikir kausalitas, emosi yang meluapluap, menarik perhatian lingkungan, dan terikat dengan kelompok.

1. Pertumbuhan Fisik

Perubahan fisik yang terjadi pada remaja berkaitan dengan pertumbuhan dan kematangan seksual. Pertumbuhan fisik seperti menghasilkan panjang lengan dan tungkai maupun tinggi badan yang tidak selalu sesuai dengan harapan remaja dan lingkungan. Perbedaan dengan fisik remaja dapat menimbulkan masalah bagi remaja sehingga sulit baginya untuk menerima keadaan fisiknya. Karena itu tugas yang harus dilakukan oleh remaja terkait dengan pertumbuhan fisik adalah bagaimana menerima keadaan fisik sebagai hasil pertumbuhan alami secara arif dan bijaksana serta tidak berbuat ke arah yang destruktif (tindakan buruk) dari keadaan fisik tersebut. 
Sebaliknya, bila pertumbuhan fisik sesuai dengan harapan dirinya dan lingkungan, juga tidak menjadikan diri kaum remaja berlaku sombong, angkuh, dan melampaui batas.

\section{Perkembangan Seksual}

Seksual mengalami perkembangan yang kadang-kadang menimbulkan masalah dan menjadi penyebab timbulnya pacaran, perkelahian, tindakan seks bebas, dan sebagainya. Tanda perkembangan seksual pada remaja khususnya putri adalah datangnya menstruasi, penimbunan lemak yang membuat buah dadanya membesar, dan sebagainya. Kondisi remaja akibat perkembangan seksual tersebut telah mendorong remaja untuk saling suka dan cinta dengan lawan jenisnya. Karena itu, akan menjadi masalah bagi remaja bila faktor lingkungan (keluarga, sekolah, dan masyarakat) kurang mau memahami dan mengerti keadaan seksual yang dihadapi remaja. Remaja akan menjadi manusia yang bersikap tertutup terhadap masalah seksual dan kemungkinan akan melakukan tindakan penyimpangan seksual. Karena itu, remaja harus dapat mengendalikan perkembangan seksualnya dengan cara mengalihkan melalui kegiatan yang produktif seperti berolahraga, mengembangkan bakat seni, dan kreativitas lainnya.

3. Cara berpikir kausalitas

Remaja juga sudah mulai menunjukkan cara berpikir kausalitas, yang menyangkut hubungan sebab akibat dan berpikir kritis. Orang tua, guru, dan masyarakat harus memperlakukan remaja sebagai individu yang memiliki potensi berpikir. Karena itu, orang tua, guru, dan masyarakat tidak boleh melakukan tindakan pemaksaan kehendak terhadap remaja, melainkan harus menerapkan cara berpikir dialogis sehingga remaja akan merasakan keberadaan dirinya dan mendorongnya untuk melakukan aktualisasi diri secara positif.

4. Emosi yang meluap-luap

Keadaan emosi remaja masih labil karena erat hubungannya dengan hormon. Suatu saat remaja bisa sedih sekali, di lain waktu remaja bisa marah sekali. Emosi yang meluap-luap itu dapat mendorong remaja melakukan tindakan yang melampaui batas kepatutan dan kewajaran. Emosi remaja lebih kuat dan lebih menguasai diri mereka daripada pikiran remaja yang realistis. Untuk itu, remaja dituntut untuk dapat mengendalikan dan mengontrol emosi.

5. Bertindak menarik perhatian lingkungan

Manusia pada masa remaja mulai mencari perhatian dari lingkungan sosialnya baik orang tua, sekolah, dan masyarakat. Karena itu, remaja berusaha mendapatkan status dan peran sosial. Tindakan remaja dalam menarik perhatian lingkungan ada yang diwujudkan dalam bentuk tindakan positif seperti belajar dan berlatih dengan rajin dan sungguh-sungguh untuk menjadikan remaja dalam berbagai bidang seperti menjadi siswa berprestasi dalam bidang akademik, juara lomba sains (fisika, kimia, biologi), juara lomba matematika, juara olahraga, juara bidang seni, dan sastra Namun, ada pula remaja yang melakukan tindakan negatif dalam rangka menarik perhatian lingkungan, seperti melakukan tindakan perkelahian, penyalahgunaan narkoba, tindakan seks bebas, dan sebagainya. Terkait dengan itu, orang tua, guru, dan masyarakat harus dapat menciptakan kondusi yang kondusif agar remaja dapat mengaktulisasikan dirinya dalam rangka menarik perhatian lingkungan sosial secara benar dan tidak melanggar norma-norma agama, sosial, dan pemerintahan. Selain orang tua, diri remaja menjadi hal yang utama dalam rangka mengendalikan dan mengontrol dirinya dalam bertindak.

6. Terikat dengan kelompok

Masa remaja dalam kehidupan sosialnya lebih tertarik dengan kelompok manusia yang sebaya dengannya. Karena itu, tidak heran bila orang tua dan guru seringkali dinomorduakan oleh remaja, sedangkan teman sebaya dinomorsatukan. Apa yang dilakukan kelompok sebaya, kemungkinan akan ditiru oleh remaja. Bila tidak mengikutinya, remaja merasa diasingkan dari kelompoknya. Keterkaitan remaja dengan kelompok mendorong lahirnya perkumpulan yang disebut "gang" Bergabungnya remaja dalam kelompok "gang", karena remaja beranggapan bahwa kelompok itu mau mengerti, mau 
menganggap dirinya dan menjadi tempat curhat serta tempat pelampiasan perasaan tertekan dan saling tukar pengalaman. Untuk itu, remaja dan lingkungan keluarga serta masyarakat dituntun untuk dapat mendorong remaja mewujudkan keterkaitan dengan kelompoknya melalui perkumpulan remaja yang positif, seperti remaja mesjid, karang taruna, kelompok ilmiah remaja, kelompok remaja pencinta alam, kelompok remaja pencinta seni dan sastra, kelompok olahraga remaja dan sebagainya.

\section{BAHAN DAN METODE}

Lokasi penelitian ini dilakukan di SMA YASPEND PABA Binjai Tahun 2017, dengan alasan berdasarkan survei awal ternyata ada masalah tentang SADARI terhadap pengetahuan dan sikap remaja putri dalamupaya deteksi dini kanker payudara.Penelitian ini dilaksanakan mulai bulan Juli- Desember 2017.
Populasi adalah seluruh objek penelitian yang diteliti. Populasi pada penelitian ini adalah remaja putri SMA PABA Binjai sebanyak 50 orang.

Sampel adalah sekumpulan data yang diambil atau diseleksi dari suatu populasi. Sampel dari penelitian ini adalah remaja putri di SMA PABA Binjai Tahun 2017. Sampel dalam penelitian ini adalah 50 responden dengan menggunakan teknik simple random yaitu mengambil 25 orang sebagai kelompok kontrol dan 25 orang sebagai kelompok perlakuan.

Penelitian ini menggunakan metode pengumpulan data dengan kuesioner dalam bentuk pertanyaan tutup.

Peneliti ingin mengetahui bagaimana pendidikan kesehatan tentang SADARI efektif untuk meningkatkan pengetahuan dan sikap remaja putri dalam upaya deteksi dini kanker payudara pada siswa SMA YASPEND PABA Binjai.

\section{HASIL PENELITIAN}

Tabel 1. Perbedaan Pengetahuan antara Kelompok Kontrol dan Kelompok Perlakuan Setelah diberikan Pendidikan Kesehatan Tentang SADARI di SMA YASPEND PABA, Binjai 2017

\begin{tabular}{cc}
\hline & Hasil Pengetahuan SADARI \\
\hline Mann-Whitney U & 0,000 \\
Wilcoxon W & 325,000 \\
Z & $-6,072$ \\
Asymp. Sig. (2-Tailed) & 0,000 \\
\hline
\end{tabular}

Berdasarkan Tabel 1 diperoleh nilai asymp.sig(2-tailed) sebesar $0,000<0,05$ maka dapat disimpulkan $\mathrm{H}_{0}$ ditolak dan $\mathrm{H}_{\mathrm{a}}$ diterima, bahwa terdapat perbedaan hasil pengetahuan antara kelompok kontrol dan kelompok perlakuan setelah diberikan pendidikan kesehatan tentang SADARI karena ada perbedaan yang signifikan maka rumusan masalah penelitianpun terjawab yakni “ Ada Pengaruh Pengetahaun Bagi Kelompok Perlakuan Terhadap Hasil Pengetahuan Remaja Putri di SMA YASPEND PABA, Binjai 2017”.

Tabel. 2. Perbedaan Sikap antara Kelompok Kontrol dan Kelompok Perlakuan Setelah Diberikan Pendidikan Kesehatan Tentang SADARI di SMA YASPEND PABA Binjai

\begin{tabular}{cc}
\hline & Hasil Sikap SADARI \\
\hline Mann-Whitney U & 1,500 \\
Wilcoxon W & 326,500 \\
Z & -6.049 \\
Asymp. Sig. (2-Tailed) & 0,000 \\
\hline
\end{tabular}

2017 
Berdasarkan Tabel 2 diperoleh nilai asymp.sig(2-tailed) sebesar 0,000 $<0,05$ maka dapat disimpulkan $\mathrm{H} 0$ ditolak dan $\mathrm{Ha}$ diterima, bahwa terdapat perbedaan hasil sikap antara kelompok kontrol dan kelompok perlakuan setelah diberikan pendidikan kesehatan tentang SADARI karena ada perbedaan yang signifikan maka rumusan masalah penelitianpun terjawab yakni "Ada Pengaruh Sikap Bagi Kelompok Perlakuan Terhadap Hasil Sikap Remaja Putri di SMA YASPEND PABA Binjai 2017”.

Tabel 3. Perbedaan Hasil Pre Test Dan Post Test pengetahuan Setelah diberikan Pendidikan Kesehatan Tentang SADARI di SMA YASPEND PABA Binjai 2017

\begin{tabular}{cc}
\hline & Posttest-Ptetest \\
\hline $\mathrm{Z}$ & $-4,374$ \\
Asymp.Sig.(2-Tailed) & 0,000 \\
\hline
\end{tabular}

Nilai asymp.sig. (2-tailled) $<0,05$ maka Ha diterima artinya ada perbedaan hasil pengetahuan pre test dan post test dimana setelah diberikan pendidikan kesehatan tentang SADARI hasil postest nilainya lebih tinggi dibandingkan hasil pre test.

Tabel 4. Perbedaan Hasil Pre Test Dan Post Test Sikap Setelah diberikan Pendidikan Kesehatan Tentang SADARI di SMA YASPEND PABA Binjai 2017

\begin{tabular}{cc}
\hline & Posttest-Ptetest \\
\hline$Z$ & $-6,158$ \\
Asymp.Sig.(2-Tailed) & 0,000 \\
\hline
\end{tabular}

\section{PEMBAHASAN}

Perbedaan pengetahuan antara

Kelompok Kontrol dan Kelompok

Perlakuan Setelah Diberikan Pendidikan

Kesehatan Tentang SADARI

Hasil penelitian yang dilakukan di SMA YASPEND PABA Binjai berdasarkan Tabel 4.1. diketahui bahwa terdapat perbedaan hasil pengetahuan antara kelompok kontrol dan kelompok perlakuan setelah diberikan pendidikan kesehatan tentang SADARI karena ada perbedaan yang signifikan maka rumusan masalah penelitianpun terjawab yakni "Ada Pengaruh Pengetahaun Bagi Kelompok Perlakuan Terhadap Hasil Pengetahuan Remaja Putri di SMA YASPEND PABA Binjai 2017"

Pengetahuan merupakan hasil "tahu" dan ini terjadi setelah orang mengadakan penginderaan terhadap objek terjadi melalui panca indera manusia yakni penglihatan, pendengaran, penciuman, rasa dan raba dengan sendiri. Pada waktu penginderaan sampai menghasilkan pengetahuan tersebut sangat dipengaruhi oleh intensitas perhatian persepsi terhadap objek, sebagian besar pengetahuan manusia diperoleh melalui mata dan telinga.

Hasil penelitian sebelumnya dengan judul "Pengaruh Pendidikan Kesehatan Tentang Sadari Melalui Metode ceramah Plus Terhadap Pengetahuan dan Sikap Siswi di SMK Swasta Arjuna Laguboti Tobasamosir Tahun 2015" Hasil analisa uji pair t-test pre test dan post test pengetahuan diperoleh nilai $\mathrm{p}=0.000$, yang berarti nilai $\mathrm{p}<0.05$ maka dapat disimpulkan ada pengaruh pendidikan kesehatan tentang SADARI terhadap pengetahuan siswi

Menurut Asumsi peneliti dari perbedaan pengetahuan yang telah didapat oleh peneliti penelitian ini sejalan dimana kelompok perlakuan memiliki hasil nilai lebih tinggi dibandingkan kelompok kontrol. 


\section{Perbedaan Sikap antara Kelompok Kontrol dan Kelompok Perlakuan Setelah Diberikan Pendidikan Kesehatan Tentang SADARI}

Hasil penelitian yang dilakukan di SMA YASPEND PABA Binjai berdasarkan tabel 4.2. diketahui bahwa terdapat perbedaan hasil sikap antara kelompok kontrol dan kelompok perlakuan setelah diberikan pendidikan kesehatan tentang SADARI karena ada perbedaan yang signifikan maka rumusan masalah penelitianpun terjawab yakni “ Ada Pengaruh Sikap Bagi Kelompok Perlakuan Terhadap Hasil Sikap Remaja Putri di SMA YASPEND PABA, Binjai 2017"

Sikap seseorang terhadap suatu objek adalah perasaan mendukung atau memihak (favorable) maupun perasaan tidak mendukung atau memihak (unfavorable) pada objek tersebut, secara spesifik Thurstone mempormulasikan sikap sebagai derajat efek positif atau negatif terhadap suatu objek psikologis.

Hasil penelitian sebelumnya dengan judul "Efektifitas Metode Simulasi terhadap Pengetahuan dan Sikap Remaja Putri tentang Upaya Deteksi Dini Kanker Payudara dengan SADARI di SMA Negeri 1 dan SMA Citra Harapan Percut Sei Tuan Kabupaten Deli Serdang" perbedaan sikap remaja pada kelompok perlakuan sebelum dan sesudah dengan nilai $\mathrm{p}=0,046$. Sedangkan pada kelompok kontrol tidak ditemukan perbedaan pengetahuan dan sikap tentang deteksi dini kanker payudara sebagai SADARI.

Menurut Asumsi peneliti dari perbedaan pengetahuan yang telah didapat oleh peneliti penelitian ini sejalan dimana kelompok perlakuan memiliki hasil nilai lebih tinggi dibandingkan kelompok kontrol

\section{Perbedaan Hasil Pre Test dan Post Test Pengetahuan Setelah diberikan Pendidikan Kesehatan Tentang SADARI}

Hasil penelitian yang dilakukan di SMA YASPEND PABA Binjai berdasarkan Tabel 4.3. diketahui bahwa Nilai asymp.sig. (2-tailled) $<0,05$ maka Ha diterima artinya ada perbedaan hasil pengetahuan pre test dan post test dimana setelah diberikan pendidikan kesehatan tentang SADARI hasil postest nilainya lebih tinggi dibandingkan hasil pre test.

Hasil penelitian sebelumnya dengan judul "Pengaruh Pendidikan Kesehatan Tentang Sadari Terhadap Pengetahuan dan Sikap Mahasiswa Dalam Upaya Deteksi Dini Kanker Payudara di Fakultas Keguruan dan Ilmu Pendidikan Universitas HKBP Nomensen Pematang Siantar Tahun 2013 " dari analisis data diperoleh bahwa ada pengaruh pendidikan kesehatan tentang SADARI terhadap pengetahuan $(\mathrm{p}=0,001)$ dan sikap $(\mathrm{p}<0,001)$ mahasiswa dalam upaya deteksi dini kanker payudara, yaitu pengetahuan bertambah tinggi dan sikap yang lebih baik

\section{Perbedaan Hasil Pre Test dan Post Test Sikap Setelah diberikan Pendidikan Kesehatan Tentang SADARI}

Hasil penelitian yang dilakukan di SMA YASPEND PABA Binjai berdasarkan Tabel 4.3. diketahui bahwa Nilai asymp.sig. (2-tailled) $<0,05$ maka Ha diterima artinya ada perbedaan hasil sikap pre test dan post test dimana setelah diberikan pendidikan kesehatan tentang SADARI hasil postest nilainya lebih tinggi dibandingkan hasil pre test.

Hasil penelitian sebelumnya dengan judul "Pengaruh Pendidikan Kesehatan Tentang Sadari Terhadap Pengetahuan Dan Sikap Remaja Putri Dalam Upaya Deteksi Dini Kanker Payudara di SMK Bisnis Manajemen Administrasi Perkantoran Bina Satria Medan Tahun 2010" dari analisis data diperoleh bahwa ada pengaruh pendidikan kesehatan tentang SADARI terhadap pengetahuan $(\mathrm{p}=0,000)$ dan sikap $(\mathrm{p}=0,000)$ responden dalam upaya deteksi dini kanker payudara.

\section{KESIMPULAN}

Berdasarkan hasil penelitian yang telah dilakukan dan disajikan pada bab sebelumnya dapat disimpulkan sebagai berikut :

1. Hasil penelitian yang dilakukan di SMA YASPEND PABA Binjai terdapat perbedaan hasil pengetahuan antara kelompok kontrol dan kelompok perlakuan setelah diberikan pendidikan 
kesehatan tentang SADARI karena ada perbedaan yang signifikan maka rumusan masalah penelitianpun terjawab yakni Ada Pengaruh Pengetahaun Bagi Kelompok Perlakuan Terhadap Hasil Pengetahuan Remaja Putri Di SMA YASPEND PABA Binjai 2017

2. Hasil penelitian yang dilakukan di SMA YASPEND PABA Binjai terdapat perbedaan hasil sikap antara kelompok kontrol dan kelompok perlakuan setelah diberikan pendidikan kesehatan tentang SADARI karena ada perbedaan yang signifikan maka rumusan masalah penelitianpun terjawab yakni " Ada Pengaruh Sikap Bagi Kelompok Perlakuan Terhadap Hasil Sikap Remaja Putri di SMA YASPEND PABA Binjai 2017"

3. Hasil penelitian yang dilakukan di SMA YASPEND PABA Binjai ada perbedaan hasil pengetahuan pre test dan post test dimana setelah diberikan pendidikan kesehatan tentang SADARI hasil postest nilainya lebih tinggi dibandingkan hasil pre test.

4. Hasil penelitian yang dilakukan di SMA YASPEND PABA Binjai ada perbedaan hasil sikap pre test dan post test dimana setelah diberikan pendidikan kesehatan tentang SADARI hasil postest nilainya lebih tinggi dibandingkan hasil pre test.

\section{SARAN}

Dari kesimpulan di atas, maka dapat disarankan pada beberapa pihak yaitu:

\section{Bagi Profesi}

Bidan mampu melanjutkan dan lebih meningkatkan perhatian terhadap pendidikan kesehatan bagi wanita khususnya tentang kanker payudara dan tindakan preventif serta promotif yaitu dengan SADARI.

\section{Bagi Institusi}

Mengembangkan kurikulum dan meningkatkan peran pendidik dalam menyampaikan pengetahuan tentang kanker payudara dan deteksi dini dengan SADARI bagi mahasiswa kebidanan secara lebih menarik sehingga mampu meningkatkan pengetahuan dan ketrampilan dalam mengaplikasikannya.

\section{Bagi Masyarakat}

Meningkatkan tindakan preventif terjadinya kanker payudara secara dini dengan cara meningkatkan pengetahuan tentang kanker payudara dan SADARI serta mampu mengaplikasikannya dalam kehidupan sehari-hari bagi masyarakat.

\section{DAFTAR PUSTAKA}

Hopkins,dkk 2008. Kanker payudara Pencegahan dan Pengobatannya, Daras books. Jakarta.

Kusmiyati, 2013. WHO: Jumlah Kematian Akibat Kanker di Dunia Meningkat.

m.liputan6.com/health/read/776217/whojumlah-kematian-akibat-kanker-diduniameningkat, diakses tanggal 16 Oktober 2017.

Globocan, International Agency for Research on Cancer (IARC), 2012.

http://globocan.iarc.fr/ia/world/atlas.html. Diakses 16 Oktober 2017

Suyatno dan Pasaribu, Emir Taris. 2010. Bedah Onkologi Diagnostik dan Terapi. Jakarta : Penerbit Sagung Seto, 35.

Pemahaman tentang kanker minim. Diambil tanggal 30 Oktober 2017 dari web site: Kriebs, J. M. \& Gegor, Carolyn L. (2010). Buku saku asuhan kebidanan varney, edisi 2. Jakarta: EGC. http://jurnalisperempuan.com/view/8/76 19/Pemahaman-tentang-

Kankerminim.html

Direktorat Jendral PP \& PL Departemen Kesehatan RI, 2014. Buku Saku Pencegahan Kanker Leher Rahim \& Kanker Payudara. Available from:http://www.pppl.depkes.go.id/_ass et/_download/bukusaku_kanker.pdf.[Ac cesed 20 Agustus 2017]

Notoatmodjo, S. 2003. Pendidikan dan Perilaku Kesehatan. Jakarta: Rineka Cipta.

2010. Ilmu perilaku Kesehatan. Jakarta: Rineka Cipta. 2012. Promosi kesehatan

dan Perilaku Kesehatan. Jakarta : Rineka Cipta.

2013. Kesehatan Masyarakat Ilmu dan seni. Jakarta: Rineka Cipta. 
Rakhmat, Jalaluddin. 2004. Metode Penelitian Komunikasi. Bandung: PT. Remaja Rosdakarya.

2005. Psikologi Komunikasi Edisi Revisi. Bandung: PT. Remaja Rosdakarya.

Niven. 2002. Skala Pengukuran Sikap. Edisi 1., Jakarta: Gramedia

Mardiana, L., 2004. Kanker Pada Wanita, Pencegahan dan Pengobatan dengan Tanaman obat. Jakarta

Smeltzer, S., 2002. Buku Ajar Keperawatan Medikal Bedah. Penerbit Buku Kedokteran EGC.Jakarta

Nugroho, Taufan. 2011. Buku Ajar Obstetri Untuk Mahasiswa Kebidanan. Yogyakarta: Nuha. Medika

Taufan, N. 2011. Asi dan Tumor Payudara, nuha Medika; Yogyakarta

Tim CancerHelps. 2010. Stop Kanker. Jakarta Selatan: PT. Agromedia Pustaka.

Robbins. 2007. Buku Ajar Patologi (Edisi 7). Jakarta. EGC.

Pierce, A., Neil, R.. 2007. Kanker Payudara. Dalam: At a Glance Ilmu Bedah. Jakarta: Erlangga, [Halaman: 130-131]

Kristiyanasari, W. 2009. Asi, Menyusui dan SADARI. Yogyakarta: Nuha Medika

Olfah, Y. 2013. Kanker Payuadara dan SADARI. Yogyakarta : Nuha Mediaka.

Suryaningsih, K. E. dan Sukaca, E.B., 2009. Kupas Tuntas Kanker Payudara. Paradigma. Indonesia: Yogyakarta.
Diananda, R., 2007. Mengenal Seluk Beluk Kanker, Yogyakarta : Katahati.

Depkes, RI, 2010. Keputusan Menteri Kesehatan Republik Indonesia Nomor 796/MENKES/SK/Tentang Pedoman Teknis pengendalian kanker Payudara Dan Kanker Leher Rahim. Jakarta.

Supit, N. 2005. Deteksi Dini Kanker. Jakarta: Fakultas Kedokteran Universitas Indonesia.

Hurlock, E, b, . 2012. Psikologi Perkembangan Suatu Pendekatan Sepanjang Rentang Kehidupan.Jakarta : Erlangga.

Widyastuti, Y., 2009. Kesehatan Reproduksi. Yogyakarta : Fitramaya

Irianto, K. 2013. Permasalahan seksual. Bandung : Yrama Widya.

Sugiyono. 2013. Metode Penelitian Pendidikan Pendekatan Kuantitatif, Kualitatif, dan R\&D. Bandung: Alfabeta.

Supranto, J. 2003. Metode Riset Aplikasi Dalam Pemasaran. Edisi Revisi Ketujuh.Yogyakarta: Rineka Cipta 